\title{
INTERNATIONAL CULTURAL RELATIONSHIPS
}

$\mathrm{T}^{\mathrm{H}}$ HE concentration which all the sources of publicity during a period of crisis must give to the War tends to diminish proper and adequate comment upon other activities within the country. It may be for this reason that but little notice has been taken of a remarkable document entitled "Greece No. 1 (1941) Convention between His Majesty in respect of the United Kingdom and His Majesty the King of the Hellenes respecting the Relations of Learning and Culture between Great Britain and Greece"*. Yet this Treaty should not go unregarded, for it marks a notable development in British relationships with foreign countries. It is a Treaty not of war and peace, nor of commercial bargaining; it is uncontaminated with the breath of propaganda; it is an attempt in an honest and unequivocal way to develop the relationships of thought and mind, of literature and science, between two great civilized peoples.

There is a dramatic propriety in the fact that the first Treaty of this kind to which Great Britain has given her signature should be with Greece. The contact of British civilization with that of Greece extends for centuries, and the basis of much of British education has been upon the classical language of that country; while from a more immediate consideration, in this hour when the face of history is being changed, Greece has been an ally that has shown that the forces of totalitarianism can be faced by resolute mind and an equal resolution in arms. Behind this document there is further a certain atmosphere of tragedy, for the signature with which it concludes is that of General Metaxas, a great friend of Great Britain, and one who had always encouraged British cultural institutions as they developed in Grecian territory. Further, though his signature nowhere appears, it is common knowledge that on the British side the initiative for this cultural bond came from that dynamic personality, Lord Lloyd, who, through the British Council, was transforming the cultural relationship of Great Britain with foreign countries.

The articles of this Treaty are modest enough. Cultural institutions in the two countries are to be given all proper encouragement and possibility for development. Students and professors and men of learning are to be welcomed equally in

* H.M. Stationery Office, $2 d$.
London and in Athens. Further, an attempt is being made to ease the entanglement of university regulations which have hampered the passage of students from one country to another and made less easy that fraternity of scholarship which existed in the Middle Ages. Above all, the British traffic of the mind in books and periodicals is to be promoted with as little impediment from customs duties, import quotas and other "relevant regulations" and all such taxes upon knowledge as may be possible.

It is particularly welcome that this Treaty of culture is not confined to any single branch of learning, but that science is to be encouraged along with art and letters. The British Council has already anticipated the action proposed by the Treaty in bringing to Great Britain a number of young Greeks, some of whom are still in British universities, and among them there are young men of science whose work has been reported as reaching a high level of distinction. Nor are the signs lacking that the British Council fully realizes that its definition of culture must include British achievements in medicine and engineering and the pure sciences, and that in due course it must organize the best of expert opinion in Great Britain to break down any intellectual insularity that may still remain. The Treaty belongs to the things which are permanent and will not only survive the War but will also become more active and real once this conflict is over. We live to-day in the sullied atmosphere of propaganda, and it may be that under the conditions of modern warfare that is inevitable; but when peace comes it is through instruments such as this cultural treaty with Greece that British contact with foreign countries should be based.

The pressure of war allows but little leisure for tributes to be paid to the dead, and the individual is likely soon to be forgotten in the major stress of events. In the few pages of this convention there remains a tribute to Lord Lloyd which should encourage those who are engaged upon the work of the British Council to increase their endeavours, and should make Great Britain affirm that in the future it will carry the best that its learning, both in the sciences and in the humanities, can give to all free peoples who may welcome such a proper and uncontaminating contact. 